Asy Syariyyah: Jurnal Ilmu Syari'ah dan Perbankan Islam - ISSN 2089-7227 (p) 2598-8522 (e)

Vol. 3, No. 2, Desember 2018, pp. 23 - 46

\title{
ANALISIS KOMPARATIF SANKSI TINDAK PIDANA PADA HUKUM PIDANA ISLAM DENGAN HUKUM POSITIF
}

\section{Reski Anwar}

IAIN Syaikh Abdurrahman Siddik Bangka Belitung

\begin{abstract}
Types of punishment provided for in the book the law of criminal law, namely criminal subject matter which consists of a criminal to death, imprisonment. As for the types of sanction or punishment in Islamic criminal law includes the law of jarimah adultery, penalty jarimah qadzaf, jarimah punishment of theft, jarimah punishment. Indonesia at the moment very much in need of a great variety of study on the concept of criminal sanctions in order to reduce islamic values through this Focus Group Discussion or conference, etc. Of a will can contribute to the renewal of a criminal law reform And there should have been a kind of work for punishment of the formulations in the form of social as well as the completion of matter outside the court (restorasi justice).
\end{abstract}

Keywords: Punishment, Criminal, Islamic

\section{A. Pendahuluan}

Masyarakat saat ini tidak dapat dipisahkan dengan hukum. Hukum sangat dibutuhkan ditengah-tengah masyarakat untuk mengatur dan menertibkan masyarakat itu sendiri. Negara Indonesia merupakan negara berdasarkan atas hukum (rechsstaat) dan tidak berdasarkan atas kekuasaan belaka (machtsstaat) ${ }^{1}$, yang artinya bahwa Indonesia mempunyai serangkaian peraturan atau hukum supaya kepentingan masyarakat dapat

${ }^{1}$ Leden Marpaung, Proses Penanganan Perkara Pidana (Penyelidikan dan Penyidikan), Sinar Grafika: Jakarta, 2009, hlm. 1. 
terlindungi. Hukum tidak dapat dipisahkan dengan masyarakat (ubi socitas ibi ius) sebab antara keduanya mempunyai hubungan timbal balik. ${ }^{2}$ Apabila dalam masyarakat terjadi suatu peristiwa yang dapat diduga merupakan suatu tindak pidana. Oleh karena itu, perilaku yang berada dalam masyarakat merupakan cerminan dari hukum yang berlaku di masyarakat tersebut.

Hukum pidana yang ada di Indonesia merupakan produk dari negeri belanda yang masih digunakan oleh bangsa Indonesia sampai saat ini. Pembahasan mengenai hukum pidana di Indonesia memuat berbagai macam jenis tindak pidana. Tindak pidana merupakan suatu perbuatan yang apabila dilanggar akan mendapatkan sanksi yang jelas sesuai dengan kitab undang-undang hukum pidana (KUHP). ${ }^{3}$

Pakar pidana Muladi mengatakan, bahwa dalam hukum pidana yang ada saat ini orientasinya pada perbuatan (Daad) dan pelaku (Daader Straafrecht), pengaturan sanksi yang ada meliputi pidana (Straff, Punishment) yang sifatnya penderitaan akan tetapi tindakan pada tata tertib yang secara relatif lebih benuansa pendidikan. ${ }^{4}$

Sebelum berbicara mengenai perbandingan sanksi pidana maupun alasan-alasan memperbandingkan, perlu terlebih dahulu mengetahui pengertian dari sanksi pidana itu sendiri apa. Menurut Hebert Packer yang dikutip Romli Atmasasmita, menyebutkan mengenai Pemidanaan pada hukum pidana: 5

"merupakan sarana terbaik yang dimiliki untuk menghadapi ancaman seketika dan akibat yang serius dari suatu kejahatan".

${ }^{2}$ Titik Triwulan Tutik, Pengantar Ilmu Hukum, Prestasi Pustaka: Jakarta, 2006, hlm 34.

${ }^{3}$ Moeljatno, KUHP, Jakarta: PT. Bumi Aksara, 2001, hlm. 32.

${ }^{4}$ Sudarto, Kapita Selekta Hukum Pidana. Alumni Bandung, hlm 16.

${ }^{5}$ Romli Atmasasmita, Sistem Peradilan Pidana kontemporer, Jakarta: Penerbit Kencana, 2010, hlm. 16. 
Selanjutnya Paccker, menjelaskan tentang adanya sanksi pada hukum pidana adalah syarat mutlak pada suatu hukuman yang tidak bisa dihindari ketika hukuman telah ditetapkan, karena disetiap lini kehidupan tentu menpunyai sanksi dan hukuman yang berbeda. Namun berbeda menurut Romli menanggapi perkataan Paccker, Sebab menurut pandangan Romli, Sanksi pidana yakni merupakan "pisau yang bermata dua" sehingga penggunaannya harus dibatasi oleh kegunaannya yang merupakan tujuan daripada sanksi pidana itu sendiri. Sebab dalam kaedahnya Romli, dia mengatakan bahwasanya di dalam upaya mencapai tujuan tersebut tidak semata-mata melalui sanksi pidana saja, akan tetapi hendaknya disadari suatu kenyataan bahwa penggunaan sanksi pidana tidak selalu harus sama bagi setiap orang karena pengertian kejahatan merupakan suatu rekayasa sosial politik yang terjadi dalam masyarakat. ${ }^{6}$

Fungsi yang mendasar adanya diformulasikan suatu aturan hukum yaitu sebagai sarana pengendalian sosial (social control enginering), yang mana didalamnya memuat instrument sanksi sebagai sarana pengontrol supaya norma yang sudah dibuat untuk selalu bisa ditaati, dengan adanya sarana pengontrol pada norma yang ada maka eksistensi hukum bias dengan mudah diterapkan secara konsisten. Penerapan hukum yang secara utuh tidak hanya memuat pada kepatutan ataupun ketaatan terhadap peraturan saat ini atau hukum positif saja, melainkan juga bisa mencakup berbagai macam norma kehidupan serta nilai-nilai yang hidup dan berkembang dalam masyarakat. Konsistensi pada formulasi penegakan hukum seyogyanya bisa mencakup segala aspek kehidupan norma adat istiadat hanya menjadi wacana yang sangat penting untuk diterapkan. Peristiwa ini yang menjadi kendala oleh kondisi kehidupan kenegaraan, sehingga banyak mengalami keterpurukan di dalam setiap lini kehidupan,

\section{${ }^{6}$ Ibid}


mulai dari bidang politik, bidang ekonomi, ataupun sosial budaya dan penegakan supremasi hukum yang pada dasarnya merupakan salah satu solusi yang paling tepat untuk memperbaiki iklim negeri hukum saaat ini. ${ }^{7}$

Saat ini penegakan supremasi kedaulatan hukum harus dilakukan perlahan-lahan dengan cara melakunan perbaikan-perbaikan, baik dari segi legal susbtansi maupun dari segi legal struktur. Perbaikan hukum mulai bisa harus dilakukan dalam sebuah proses pembentukan peraturan perundang-undangan dan juga pembenahan dan peningkatan kualitas sumber daya aparat penegak hukum serta budaya hukum (legal culture).

Dilihat dari segi sisi peraturan perundang-undangan yang ada pada saat ini, berkualitasnya sebuah peraturan harus bisa benar-benar diperhatikan secara lebih seksama yang mana pada substansi materi sebuah peraturan harus selaras dan relevan dalam hubungannya dengan peraturan perundang-undangan lain ataupun nilai-nilai yang hidup didalam masyarakat.

Faktor pendorong salah satu adanya kepatuhan dan ketaatan individu pada hukum tidak lain karena adanya sanksi sehingga tidak dapat dibayangkan bagaimana jika hukum dapat mengikat tanpa adanya sanksi, apakah berlaku efektif atau sebaliknya. Hukum pidana misalnya yang memiliki sistem hukum yang berbeda dengan bidang hukum lainnya yang lebih mendasarkan pada pokok pelaksanaan sanksinya, dan juga pada sanksi fisik yang banyak menimbulkan pro dan kontra terhadap sanksi pidana yang dijatuhkan oleh hakim, baik dikalangan praktisi hukum maupun akademisi hukum itu sendiri terlebih lagi dikalangan masyarakat pencari keadilan.

Hukum pidana yang dikehendaki saat ini hendaknya setiap hubungan kemasyarakatan tidak boleh bertentangan dengan peraturan-peraturan

${ }^{7}$ Ahmad Ali, Keterpurukan Hukum di Indonesia, Penerbit Ghalia: Indonesia, Bogor Cetatakan ke- II, 2005, hlm. 1. 
hukum yang ada serta norma yang hidup berlaku dalam masyarakat. Adapaun deraan yang bersifat hukuman (pidana) bisa dikenakan kepada setiap pelanggar peraturan hukum yang ada sesuai dengan norma yang telah disepakati sebelum peraturan itu dibuat, hal itu senada sebagai konsekuensi terhadap perbuatan yang menabrak peraturan hukum yang dilakukannya.

Maka dari itu adapun efek dari akibat yang ditimbulkan ialah kebijakan yang ada pada prinsip dan norma-norma hukum yang ada haruslah sesuai dengan pilar-pilar keadilan yang ada dalam masyarakat, tujuannya untuk menjaga agar prinsip-prinsip dasar hukum bisa dapat berlangsung terus dan mampu diterima bagi seluruh elemen masyarakat. ${ }^{8}$

Pada prinsipnya dalam hukum pidana dikenal dengan tiga landasan pemikiran mengenai tujuan yang ingin dicapai terhadapn suatu pemidanaan, yaitu : yang pertama sebagai sarana untuk membenahi person pribadi dari pelanggar itu sendiri, yang kedua untuk membuat orang menjadi tobat dalam melakukan kriminalitas dan yang ketiga untuk mengontrol pelanggar tertentu menjadi tidak mampu melakukan kriminalitas yang lain.

Jika diitinjau dari tujuan deraan pada pemidanaan di atas kita bisa memulai dengan melakukan suatu kajian yang tepat pada instrument yang efektif dalam membangun sistem hukum yang ideal saat ini. Pada sanksi sosial yang hidup dimasyarakat jauh lebih efektif sebagai sarana memberantas serta pengendali perilaku criminal yang sering muncul, Sanksi pidana seperti ini yang seharusnya bisa diharapkan untuk mengkaji dan juga bisa menerapkannya paling tidak untuk menanggulangi kriminalitas yang seyogyanya dapat memangkas jenis tindak pidana yang ada di Negara saat ini. Ketidak ampuhan sanksi pidana di negara saat ini

8 Sholehuddin, M. Sistem Sanksi dalam Hukum Pidana: Ide Dasar Double Track System dan Implementasinya. PT Raja Grafindo Persada: Jakarta, 2007, hlm. 70-71 . 
disebabkan oleh komposisi hukum pidana yang tidak bisa berproses seperti yang diharapkan. Jadi, hal demikian ini bisa digunakan sebagai tolak ukur bahwasannya alat yang digunakan untuk mengancam, yakni sanksi pidana, juga tidak berjalan sesuai dengan yang diharapan.

Oleh karenanya kita merasa tertarik untuk menggagas sebuah atrtikel pada perbandingan jenis model sanksi pidana positif dan hukum pidana islam yang insya Allah bisa dijadikan masukan serta mampu berkontribusi pikiran dalam hal pemecahan masalah beserta jalan keluarnya.

Hukum pidana yang ada pada civil-law system, common-law system, hukum pidana islam (figh-jinayah) semoga bisa mampu sebagai penyelesaian dari masalah yang sedang dicari dan dapat dijadikan sebagai penyelaras dalam ruang lingkup dan peranan perbandingan hokum yang bersifat konstruktif untuk kemudian diserahkan kepada pakar hukum untuk bisa ditelaah atau diterapkan pada situasi yang relevan. ${ }^{9}$

Hal menarik yang dapat diangkat sebagai dasar hukum pada konteks pidana Islam bisa sebagai penyelaras karena hal demikian bisa ditinjau dari sudut konstitusi yamg ada pada saat ini. Bisa dilihat Pada pasal 29 ayat (1) Undang-Undang Dasar 1945 disebutkan bahwasannya : ${ }^{10}$

Negara (Republik Indonesia) berdasarkan atas Ketuhanan Yang Maha Esa.

Norma dasar yang terkandung dalam pasal 29 ayat (1) itu tafsirannya antara lain: Negara Republik Indonesia tidak boleh terjadi atau berlaku sesuatu yang bertentangan dengan kaidah Islam bagi umat Islam, atau yang berseberangan dengan kaidah atau norma agama lain seperti agama nasrani bagi umat nasrani, atau yang bertentangan dengan kaidah norma agama hindu bagi orang-orang hindu balinya atau yang bertentangan dengan norma kesusilaan agama budha bagi pengikutnya. Hal ini berarti

\footnotetext{
${ }^{9}$ Muslich, Ahmad Wardi, Pengantar dan Asas Hukum Pidana Islam (Fikih Jinayah), Sinar Grafika: Jakarta, 2004, hlm. 1.

${ }^{10}$ Lihat Pasal 29 ayat (1) UUD 1945.
} 
bahwasannya Negara tidak bisa melegalkan hukum yang bertentangan dengan kaidah-kaidah (hukum) agama dan norma kesusilaan bangsa Indonesia.

Negara Kesatuan Republik Indonesia wajib menjalankan syariat Islam bagi orang Islam, syariat Nasrani bagi orang Nasrani dan syariat Hindu bagi orang Hindu-Bali bagi orang Bali, sekadar menjalankan syariat tersebut memerlukan perantaraan kekuasaan melalui Negara. Syariat yang tidak memerlukan bantuan kekuasaan untuk melaksanakannya karena dapat dijalankan sendiri oleh setiap pemeluk agama yang bersangkutan, menjadi kewajiban pribadi pemeluk agama itu sendiri.

\section{B. Pembahasan}

Hukum pidana yang diterapkan di Indonesia saat ini mengadopsi dari berbagai sumber, antara lain berasal dari hukum belanda, hukum adat dan hukum Islam. Butuh elaborasi yang secara runtut mengenai makna daripada hukum itu sendri. Penjelasan tentang hukum pidana yang merupakan sebagai entitas studi. Mengutip pendapat Heijder dia mengatakan dalam metode hukumnya bahwa hukum pidana itu beberapa macam bidang ilmu seperti Ilmu-ilmu hukum pidana sistematik, dan Ilmu hukum pidana berdasarkan pengalaman. ${ }^{11}$ Penggolongan Hukum Pidana dalam Istilah hukum pidana mulai diberlakukan sejak zaman Indonesia dijajah Jepang Osamu Seirei untuk bahasa belandanya strafrecht, karena untuk memisahkannya dari terminologi hukum perdata.

Penjelasan pada istilah Pidana (hukuman) adalah hukum yang merancang mengenai formulasi pidana dan tata proses pemidanaan. Istilah yang muncul pada konteksnya pidana terkadang suka diatafsirkan dengan tafsiran hukuman. Padahal pengertian hukuman yang ada merupakan hlm. 1.

11 Andi Hamzah, Asas-Asas Hukum Pidana, Rineka Cipta: Jakarta, Cetakan ke-III, 2008, 
suatu pengertian bersifat umum, seperti seuatu yang menderakan atau nestapa yang dikenakan kepada seseorang atau badan hukum dengan sengaja.

Hukum pidana biasanya bisa menggambarkan salah satu bagian dari semua citra keseluruhan komposisi hukum yang berlaku dinegara tersebut, tentu didalamnya memuat dasar kaidah atau aturan norma yang dapat untuk memformulasikan serta mensyaratkan tindakan seperti apa yang tidak diperkenankan, yang tidak diperbolehkan, yang seraya disertai dengan hukuman atau sanksi pidana tertentu bagi siapa saja yang menabrak larangan tersebut. Bagian dari diciptakannya pidana yakni untuk menenntukan dimana dan dalam kondisi apa saja bagi pelanggar yang telah menabrak aturan-aturan itu yang tentunya dapat dikenakan atau dijatuhi sanksi pidana sebagaimana yang telah diderakan sebelumnya, untuk menentukan dengan cara seperti apa susunan sanksi pidana itu dapat dijalankan jika ada pelanggar yang telah disangka saat menabrak aturan dengan cara pemberian efek jera berupa sanksi sosial yang hidup dalam komunitas masyarakat itu sendiri. Efek yang ditimbulkan akan membuat para pelanggar menjadi insyaf. Insya Allah.

Pakar pidana Sudarto juga mengemukakan dalam ilmu hukum ada perbedaan antara istilah "pidana" dengan istilah "hukuman", beliau mengatakan bahwasanya istilah "hukuman" kadang-kadang digunakan untuk pergantian perkataan "strafft", tetapi menurut beliau istilah "pidana" lebih patut digunakan daripada menggunakan istilah hukuman. Selanjutnya menurut muladi dan barda nawawi arief istilah yang dipakai didalam hukuman merupakan sebutan yang sangat global dan konvensional, hal demikian juga dikatakan bisa memiliki makna yang jauh dan berganti-ganti sebab istilah yang timbul dapat berimplikasi dengan bidang yang mumpuni. Makna dari istilah diatas tadi bukan hanya sering dipergunakan pada bidang kajian ilmu hukum semata akan tetapi juga 
pada konsep sehari-hari dibidang pendidikan, sosial, moral, agama, dan seterusnya. Oleh sebab itu pada hukuman yang ada pada hokum pidana tersebut harus memiliki istilah yang lebih spesifikasi, jadi sangat diperlukan sekali adanya sekat-sekat pembatas antara pengertian atau makna khusus yang dapat menunjukan cirri-ciri atau sifat-sifatnya yang khas". ${ }^{12}$

Istilah yang memuat pada tindak pidana yaitu Kitab Undang-Undang Hukum Pidana (KUHP) oleh perancang undang-undang sering digunakan dengan sebutan "strafbaarfeit". Perancang undang-undang tersebut tidak memberikan secara spesifikasi yang signifikan mengenai penjelasan tindak pidana tersebut yang secara ekplisit lebih lanjut seharusnya bisa memberikan mengenai makna dari arti strafbaarfeit itu sendiri, agar pelaksanaan pada peggunaannya bisa lebih jelas. Oleh karenanya terhadap maksud dan tujuan adanya sebutan strafbaarfeit tersebut sering dipergunakan oleh pakar hukum pidana dengan istilah tindak pidana, perbuatan pidana, peristiwa pidana, serta delik. ${ }^{13}$

Sedangkan pidana bisa diartikan sebagai suatu pengertian yang khusus saling berkaitan dengan hukum pidana. Maksud daripada pengertian khusus tersebut masih juga terdapat berbagai macam persamaan dengan pengertian umum, seperti berkenaan dengan sanksi deraan atau nestapa yang menderitakan.

Pakar pidana andi hamzah juga mengatakan mengenai istilah pidana harus dikaitkan dengan persyaratan yang termaktub pada pasal 1 ayat (1) Kitab Undang-Undang Hukum Pidana atau bisanya sering disebut sebagai asas legalitas yang berbunyi:

"nullum delictum nulla poena sine praevia lege poenali".

12 Muladi dan Barda Nawawi Arief, Teori - teori dan Kebijakan Hukum Pidana, Alumni: Bandung, 2005, hlm. 1.

13 Ibid. 
Sebutan tersebut diungkapkan oleh Anselm von Feurbach, yang berbunyi sebagai berikut: ${ }^{14}$

"Tiada suatu perbuatan dapat dipidana, kecuali berdasarkan kekuatan ketentuan perundang-undangan pidana yang telah ada sebelumnya."

Belanda didalam bahasanya cuma mempunyai satu pengertian sebagai persamaan istilah hukuman ataupun pidana seperti straf. Oleh karenanya pidana membentuk dengan sebuah sebutan yang lebih terperinci khusus, maka dari itu penting adanya kualifikasi pada istilah atau makna tersentral yang bisa menunjukkan ciri-ciri atau sifat-sifatnya yang khas. Untuk memberikan gambaran yang lebih luas, berikut ini ada beberapa buah piker pendapat dari para sarjana yakni:

Sudarto mengungkapkan bahwasannya yang dimaksud dengan pidana adalah penderaan yang segaja dikenakan beban pada orang yang melakukan tingkah laku perbuatan yang memenuhi kondisi pada ketentuan syarat-syarat tertentu. ${ }^{15}$

Roeslan Saleh juga mengutarakan mengenai istilah pidana ialah hubungan timbal-balik atas delik dan ini berupa suatu suatu deraan nestapa yang dengan sengaja dikenakan oleh negara pada pelanggar delik tersebut. 16

Pada beberapa keterangan diatas, Muladi meringkaskan bahwa pidana berisi beberapa unsur- ciri sebagai berikut :17

1. pidana itu pada dasarnya merupakan suatu kondisi penderaan atau nestapa serta dampak-dampak lainnya yang tidak mensejahterahkan;

${ }^{14}$ Andi Hamzah, Sistem Pidana dan Pemidanaan Indonesia (revisi), Paradnya Paramitha: Jakarta, 1993, hlm. 1.

${ }^{15}$ Sudarto, Hukum dan Pidana, Alumni: Bandung, 1977, hlm. 109-110.

16 Roeslan Saleh, Stelsel Pidana di Indonesia, Bina Aksara: Jakarta, 1987, hlm .5.

17 Muladi dan Barda Nawawi Arief, Teori-Teori dan Kebijakan Pidana (Edisi Revisi), Alumni: Bandung, 1998, hlm. 4. 
2. pidana itu dikenakan dengan sengaja oleh perancang atau badan yang mempunyai kewenangan;

3. pidana itu dikenakan kepada individu yang sudah melangsungkan tindak pidana menurut peraturan yang berlaku;

Selanjutnya ted honderich mempunyai pendapat mengenai pemidanaan setidaknya ada memuat 3 (tiga) unsur sebagai berikut :18

Pertama, pemidanaan harus memiliki kandungan semacam kerugian atau penderitaan (distress) yang bisa diformulasikan sebagai tujuan dari reaksi atas pemidanaan tersebut.

Kedua, setiap pemidanaan hendaknya berasal dari lembaga-lembaga yang berkuasa secara ketetatapan hukum pula sudah diberi kewenangan. Ketiga, pejabat yang berkuasa mempunyai hak untuk memberikan vonis dalam hal pemidanaan yang hanya kepada individu yang telah terbukti dengan sengaja melabrak hukum atau peraturan yang berlaku dalam lingkungan masyarakat.

Unsur ketiga ini menuai pertanyaan mengenai sanksi yang kolektif seperti halnya memboikot produk pokok yang sewaktu-waktu bisa dialami oleh orang-orang yang tidak bersalah. Dengan demikian, secara umum seyogyanya pemidanaan dapat dirumuskan secara terbuka sebagai ganti kerugian-denda yang diberikan oleh lembaga yang berwenang kepada pelanggar hukum atau peraturan.

Adapun tujuan dari pemidanaaan secara preventif ntuk menakutnakuti orang agar tidak melakukan kejahatan, dan menakut-nakuti orang tertentu yang telah melakukan kejahata. Selain itu juga untuk mendidik atau memperbaiki orang yang sudah melakukan kejahatan agar tidak melalukan kejahatan yang sama.

18 Sholehuddin, M., Sistem Sanksi dalam Hukum Pidana: Ide Dasar Double Track System dan Implementasinya, ... , hlm. 70-71 . 
Sanksi pidana yang dijatuhkan kepada pelaku kejahatan dapat digolongkan menjadi dua macam yaitu pidana pokok dan pidana tambahan. Adapun dari berbagai macam jenis sanksi pidana terkandung beberapa jenis sanksi pidana yang meliputi pidana mati, pidana seumur hidup, pidana penjara, pidana kurungan, pidana denda yang meliputi pidana pokok serta pidana yang berupa pencabutan hak-hak tertentu, penyitaan barang-barang tertentu, dan pengumuman putusan hakim yang kesemuanya merupakan pidana tambahan. ${ }^{19}$

Hukum pidana Islam memiliki tiga muatan yang esensial sebagai dasar yang fundamental, seperti adanya tindak pidana kisas-qisas pemberian hukuman yang setimpal, hudud pemberian hukuman sesuai dengan syariat yang telah ditetapkan oleh Allah, dan takzir seperti halnya kebijaksanaan oleh hakim. Ada juga penulis yang hanya membagi menjadi dua bidang pokok, yaitu tindak pidana hudud dan takzir. Pembagian versi kedua ini disebabkan oleh adanya perspektif bahwa hudud adalah semua jenis tindak pidana yang secara tegas diatur dalam Al-quran dan hadist. Baik berupa sifat perbuatan pidana maupun sanksi hukumnya, sehingga tindak pidana qisas masuk ke dalam ranah hudud. Sementara itu, semua jenis tindak pidana yang tidak masuk ke dalam ranah hudud berarti masuk ke dalam wilayah takzir. ${ }^{20}$

Apabila penggolongan pada hukum pidana islam mengikuti versi pertama diatas tadi yang berupa kisas, hudud, dan takzir. Adapun Qisas berisi mengenai dua macam jenis, yakni qisas yang bersifat dalam hal tindak pidana pembunuhan dan penganiayaan. Tindak pidana hudud mempunyai cakupan yang cukup banyak setidaknya ada tujuh macam jenis, yakni seperti tindak pidana penuduhan zina, perampokan, perzinaan, pencurian, perbuatan meminum khamar atau penyalahgunaan narkoba,

${ }^{19}$ Lihat Pasal 10 Kitab Undang-undang Hukum Pidana 
pemberontakan, dan perbuatan murtad. Berikutnya ada kisas dan hudud namun masuk ke dalam bidang jarimah yang dikenakan dengan sanksi hukuman berupa takzir, yaitu hukuman yang ditentukan oleh yuridiksi yang berkuasa pada sebuah konvensi atau negara tertentu.

Pengertian Fiqh atau Syariah yang memuat pada Istilah Fikih merupakan suatu sebutan yang bersumber dari bahasa Arab, yang memiliki arti kecerdasan, tahu atau paham atau pemahaman ataupun pengertian yang mengetahui sesuatu pemahaman dengan sempurna secara runtut dan tepat sesuai dengan ilmu dan bidang pemahamannya, sedangkan makna terminologisnya telah diringkas oleh para pemikir atau pakar hukum Islam, diantaranya:21

Asaf Ali Asgar Fryzee, mengungkapkan istilah mengenai fikih sebagai pandangan wawasan tentang hak dan kewajiban-kewajiban individu seperti mana yang diketahui dari al-qur'an dan sunnah, alias seperti yang dirumuskan dari keduanya atas apa dari beberapa kaum yang sepakat.

Ash-shidieqy, mempunyai pandangan lain mengenai istilah fikih yakni bidang disiplin ilmu yang banyak mendeskripsikan berbagai jenis hukumhukum syarah yang didapatkan dari kaidah norma-norma dalam rumusan yang secara terperinci atau tafsili.

Muhazzir Budiman, memiliki pengertian mengenai istilah fikih yaitu sebagai ilmu pengetahuan yang mempunyai wawasan pandangan hukum yang sifatnya meliputi berbagai bidang amaliyah yang mana pandangan mengenai wawasan pengetahuan hukum itu berakar dari hasil ijtihad.

Asal-usul istilah dari fikih jinayah, kata jinayah bersumber dari bahasa arab yang memiliki makna secara etimologis yang merupakan nama dari hasil tindakan perbuatan individu yang bersifat negatif dari apa yang telah dilakukannya. Makna dari istilah seperti ini bersifat infinitive yang sering

${ }^{21}$ Hamid, H. M. Arifin, Hukum Islam Perspktif Keindonesiaan (Sebuah Pengantar dalam Memahami Realitasnya di Indonesia), Edisi Internal: Palu, 2008. hlm. 1. 
digunakan sebagai kata bendadan berasal dari idiom yang mempunyai konstruksi berarti "seseorang telah berbuat jahat kepada orang lain". Kata Jinayah sering digunakan dalam arti ini, adapun didalam istilah hukum mempunyai implikasi bahwasannya segala macam jenis tingkah laku perbuatan yang tidak dibenar oleh dalil-dalil hokum (peraturan yang berlaku).

Makna dari arti secara terminologinya, telah diungkapkan dari beberapa pemikir hukum pidana Islam, diantaranya:22

Istilah jarimah atau jinayah diungkapkan oleh abdul al-selan qadir awdah yakni merupakan suatu tindakan, perilaku yang tidak dibenarkan oleh syarah baik halnya tindakan tersebut seperti mengenai jiwa, harta benda, dan seterusnya. Jinayah lebih menekankan kepada suatu perbuatan yang tidak dibenarkan/ dilarang oleh syarah sebab akan memberikan dampak yang berbahaya bagi jiwa, harta, keturunan, maupun akal sehat. Selain itu juga imam mawardi, memiliki definisi yag mirip mengenai jarimah atau jinayah itu yakni sebagai sebuah tidnakan perilaku individu seseorang yang mempunyai larangan-larangan sesuai syarah yang diancam oleh Allah dengan hukuman had atau takzir.

Topo Santoso memberi istilah diatas yakni sebagai suatu hal yang dilarang dalam hukum sesuai dengan yang telah Allah ditetapkan didalam syariat Islam, yang apabila pelanggaran tersebut ditabrak maka akan membawa dampak hukuman yang telah ditentukan-Nya. Tindakan dari hukuman tersebut berarti memiliki makna telah melakukan suatu tindakan yang tidak dibenarkan secara syariat. Dengan demikian, suatu kejahatan adalah segala macam jenis tindakan yang hanya dilarang oleh syariat yang ada. Dengan makna lain juga, bahwa melakukan segala macam jenis ,hlm. 1.

${ }^{22}$ Muslich, Ahmad Wardi, Pengantar dan Asas Hukum Pidana Islam (Fikih Jinayah), ... 
perbuatan yang tidak dibenarkan oleh hukum syarah maka akan membawa kepada hukuman yang ditentukan oleh syariat. ${ }^{23}$

Asaduloh al-faruk, memberikan pengertian jarimah sebagai sebuah tindakan yang dilarang disertai dengan sanksi yang jelas bagi setiap individu yang melanggar berdasarkan al-quran, as-sunnah dan ijmak. ${ }^{24}$

Unsur jarimah dikelompokan jadi 2 bagian unsur, yakni unsur umum dan unsur khusus. Unsur umum pada jarimah ini dapat digolongkan menjadi tiga macam, seperti:

Unsur formil yang merupakan jika suatu tindakan yang tidak dianggap melawan hukum maka pelaku tersebut pasti tidak akan dapat dikenakan sanksi kecuali adanya nash atau kebiajakan suatu peraturan perundangundangan yang mengaturnya. Hal ini sama dengan ada konsep asas legalitas dalam hukum positif.

Selanjutnya ada unsur materil, yakni, tingkah laku, tindakan, perbuatan seseorang yang membentuk jarimah itu sendiri secara positif atau negatif atau bahkan baik dengan sikap berbuat maupun dengan perilaku yang tidak berbuat. Hal demikian dengan adanya percobaan pada kategori unsur sengaja atau tidak sengaja yang sering muncul dama rumusan delik pada hokum pidana positif.

Unsur yang ketiga yakni moril, pelaku jarimah merupakan subjek yang bisa dikenakan pertanggungjawaban pidananya terhadap apa (jarimah) yang telah dilakukannya. Pada unsur ketiga ini memiliki makna dari unsur khusus yang hanya terdapat pada peristiwa pidana tertentu dan berbeda antara unsur khusus pada jenis tindak pidana (jarimah)yang satu dengan jenis tindak pidana lainnya.

\footnotetext{
${ }^{23}$ Topo Santoso, Membumikan Hukum Pidana Islam: Penegakan Syariat dalam Wacana dan Agenda, Gema Insani Press, 2003, hlm. 20.

24 Asadullah, Alfaruk, Hukum Pidana dalam Sistem Hukum Islam, Pnerbit Ghalia Indonesia: Bogor, 2009, hlm. 5.
} 
Ada banyak cara untuk memberi efek jera terhadap seseorang yang telah melakukan tindak pidana, namun hal demikian yang menjadi tujuan tercapainya hokum pidana sering menjadi upaya terakhir dalam proses peradilan. Dalam hal ini yang menjadi akar permasalahan mengenai adanya dasar pembenaran pemidanaan yang menjadi landasan permasalahan utama tentang penjatuhan pidana dari pembuat kebijakan kepada subjek tindak pidana. ${ }^{25}$ berkenaan dengan hal demikian akan mengulas dari beberapa titik pangkal refleksi tentang esensi pembenaran pemidanaan sebagai acuan pembenaran proses peradilan dengan menggunakan dasar pembenaran dalam filsafat dan dasar perlindungan hukum.

Pada topik pembenaran pemidanaan ini, ada pendapat muladi, beliau menyatakan bahwasannya pada teori absolut dasar pembenaran pemidanaan dikenakan kepada subjek hukum dikarena subjek hukum tersebut telah melakukan suatu tindak kejahatan yang dilarang oleh undang-undang. Pada teori relative juga memuat mengenai pemidanaan tidak hanya sebagai pembalasan dari kesalahan akan tetapi untuk melindungi masyarakat agar sejahtera dan aman. Hal ini tentunya merupakan bagian dari tujuan alasan adanya pemidanaan.

Formulasi hukuman yang termaktub dalam kacamata dunia islam memuat tiga jenis sanksi dalam dimensi keyakinannya yang berlandaskan pada keimanan sebagaimana sanksi yang sifatnya konvensional yakni berupa peringatan dan pembelajaran, sanksi hukuman yang memuat interaksi yang riil empiric dilapangan dan alamiah sebagai dosa konsekuensinya atas apa perbuatannya yang telah dilaukan didunia, hukuman sebagai pengejewantahan manifestasi perwujudan dosa yang

${ }^{25}$ Muladi dan Barda Nawawi Arief, Op., Cit., hlm. 4. 
tidak akan terpisahkan darinya atau seperti balasan di akhirat yang ada didalam ketentuan quran dan sunnah. ${ }^{26}$

Hakikatnya pemaknaan etika yang ada dalam hukum Islam sangatlah banyak perbedaan pada konsep hukum kovensional yang ada. Ada beberapa hal yang semestinya tidak dapat dipungkiri mengenai perbedaan pertama diatas tadi yang paling fundamental dan yang paling tegas dikatakan, bahwasannya hukum yang ada saat ini (hukum barat) bersifat sekuler yang orientasinya hanya kepada pelaku sedangkan pada hukum Islam (pidana) hakikinya bersifat keagamaan yang lebih mengutamakan sisi kemanusiaan yang sudah benar tidak ada lagi keraguan didalamnya. Kodifikasi hukum yang ada saat ini berasal dari hukum romawi yang merupakan hukum buatan manusia sewaktu-waktu bisa berubah apabila suasana menghendaki demikian, sebagaimana ketika hukum tersebut disusun sebelumnya. Lain halnya dengan hukum Islam (pidana) yang secara dasar pilar-pilar kegamaan dianggap sebagai hukum Tuhan yang pada hakikatnya tidak dapat dirubah.

Pada setiap muslim ada beberapa nilai moral-etik didalam agama tidak semuanya mampu mengjangkau dengan akal nalar manusia, sebab akal sehat manusia terbatas dan pasti tidak akan bisa mencapai nilai Tuhan yang maha luas karena dalam aspek illahi tuhan mengetahui apa yang tidak ketahui oleh mahluknya sebab dalam hubungan ini manusia sepenuhnya terikat dengan apa yang sudah di wahyukan tuhan. Maka itu segala macam jenis tindakan perilaku manusia tercakup dan dibagi menurut kaedah yang secara merata yang diakui secara sah oleh syariat, adapun 5 macam penggolongan seperti wajib, sunnah, mubah, makruh dan haram sesuai dengan ketetapan Allah. Jadi dapat dikatakann bahwa hukum islam (pidana) cakupan untuk memahami ilmunya lebih luas

26 Muslich, Ahmad Wardi, Pengantar dan Asas Hukum Pidana Islam (Fikih Jinayah), Sinar Grafika: Jakarta, 2005, hlm. 1. 
mengingat ada lima klasifikasi diatas dibandingkan dengan hukum kodifikasi yang ada saat ini.

Para ahli hukum barat mengatakan bahwasanya hukum yang diterapkan harus sesuai dengan ketentuan yang berlaku tidak bisa berlaku surut sesuai dengan asa yang sudah ditentukan sebelumnya dan diberlakukan pada kondisi yang sudah dibuat melaui peradilan hukum. Namun hukum Islam (pidana) bisa mencakup segala aspek hukum baik hukum publik, hukum privat, hukum nasional dan hukum internasional sekaligus.

Mulai berlakunya hukum pidana islam atau fikih jinayah sejak diutusnya nabi terakhir sebagai bagian dari syariat islam yang harus disampaikan kepada umatnya. Pada hukum pidana islam dalam masa kenabian rasulullah dan khulafaurrasyhidin secara legal digunakan sebagai hukum public yang mengatur segala macam jenis hukum yang disahkan oleh lembaga pada saat itu yang sah atau (ulil amrii), kepemimpinanya pada masa itu dirangkap oleh rasulullah sendiri dan kemudian diganti oleh khulafaurrasyhidin.

Banyak kisah mengenai pengimplementasian dalam penerapan hukum pidana atau fikih jinayah masa kenabian rasulullah, seperti kisah Maiz yang menyatakn dirinya telah melakukan perbuatan yang terhina (zina) maka maiz atas tindakanya dikenakan hukum rajam dan peminum khamr juga pada saat itu dikenakan hukuman cambuk 40 kali. Setelah rasul wafat digantikanlah oleh abu bakar, hukuman tersebut masih tetap diberlakukan jika ada menemukan tindakan yang serupa maka hukuman cambuk masih diberlakukan. Namun berbeda saat khalifahnya umar bin khattab terjadi kasus maraknya minum-minuman keras yang beredar pada saat itu, sehingga umar mengadakan pertemuan dengan para sahabat lainnya untuk 
menentukan jenis banyaknya sanksi hukuman bagi peminum khamr yang pada akhirnya dapatlah diputuskan cambuk sebanyak 80 kali. ${ }^{27}$

Hukum pidana islam ini berlaku dan sering digunakan sampai dengan masa pemerintahan Bani umayah, abasiyyah, dan turki utsmani yang masa pemerintahannya masih menggunakan dengan sistem pemerintahan Islam. Setelah masa itu Negara-negara Islam pada umumnya menjadi negara jajahan eropa. Akibat dari pengaruh jajahan eropa tentunya memiliki dampak juga pada regulasi yang dibuat sejak masa jajahannya tersebut termasuk bidang hukum, khususnya hukum pidana, namun sampai dengan saat ini masih ada beberapa negara yang mencoba menggunakan syariat Islam sebagai dasar negaranya, mulai mencoba untuk menerapkan sistem hukum pidana islam.

Sistem yang ada pada hukum pidana dalam islam memiliki dua tipe cara, yakni: dengan menentukankan hukuman yang berlandaskan atas nash, serta menyerahkan penetapan tersebut kepada pemimpin (ulill amrii). Pada cara yang pertama dalam syariat islam bahwasannya pemguasa/ pemimpin tidak diperkenankan memberikan hukuman yang menyimpang dari ajaran yang sudah ditetapkan dalam al-quran dan sunnah. Sanksi yang terdapat dalam klasifikasi ini tidak akan berubah sebab sudah mempunyai ketentuan dalam alquran dan sunnah, hal inilah yang membedakan system yang ada dalam hukum Pidana Islam dengan hukum pidana yang berlaku sekarang di berbagai belahan negara.

Sistem hukum pidana islam memiliki beberapa bagian tindak pidana, adapun klasifikasi tindak pidana yang ada dalam hukum pidana islam ada 8 macam, yakni: tindak pidana pada pencurian, perzinahan, menuduh berzina (qadzaf), minum-minuman beralkohol (memabukkan), keluar dari islam (jarimah riddah), penganiayaan, pemberontakan dan pembunuhan.

${ }_{27}$ Badri Yatim, Sejarah Peradaban Islam, Jakarta: PT Raja Grafindo Persada, 2004, hlm. 37 
Semua tindak pidana tadi (kecuali pembunuhan-penganiayaan) masuk dalam kategori jarimah hudud yang hukumannya merupakan hak Allah dan hak masyarakat. Sedangkan tindak pidana yang ada pada pembunuhan dan penganiayaan masuk kategori jarimah qisas yang hukumannya merupakan hak individu.

Terlihat jelas perbedaan prinsip antara hak Allah-masyarakat dengan hak individu terletak dalam masalah pengampunan. Pada kategori hukuman hudud tidak ada pengaruh pengampunan (amnesti) terhadap hukuman (sanksi), sedang dalam hukuman qisas ada pengaruh pengampunan yang diberikan kepadakan korban atau keluarganya. Pada jenis kategori kedua, hukum pidana islam memberikan kesempatan yang seluas-luasnya terhadap ulil amri atau pemimpin untuk menentukan kebijakan pada jenis macam-macam tindak pidana serta sanksi yang tegas kepada pelaku tindak pidana. Tentunya pemimpin juga memberikan penjabaran yang jelas dan tegas terhadap pelaku tindak piadana yang sesuai dengan ketentuan didalam alqur'an dan sunnah.

Klasifikasi pada ketentuan umum tersebut menerangkan bahwasannya setiap perbuatan tindak pidana (jarimah)yang merugikan, baik terhadap individu ataupun masyarakat, haruslah sesuai dengan ketentuan syariat islam sebab faedah dan efek yang ditimbulkan jauh lebih efektif. Tindak pidana dalam jarimah takzir yang hukumannya disebut dengan hukuman takzir.

\section{Penutup}

Berdasarkan kesimpulan dari uraian diatas dapat dirangkum dengan beberapa hal sebagai berikut: Jenis saknksi/ hukuman yang ad diatur dalam kitab undang-undang hokum pidana yakni pidana pokok terdiri dari pidana mati, pidana penjara, pidana kurungan, pidana denda. Serta adapun jenis sanksi/ hukuman pada fikih jinayah (hukum pidana islam) 
meliputi hukum jarimah zina; hukuman jarimah qdzaf, hukuman jarimah pencurian; hukuman jarimah hirabah (perampokan); hukuman jarimah ta'zir.

Perbandingan antara kedua jenis hukuman terdapat beberapa psamaan dan perbedaan dari pola yang ditentukan dalam pemidanaan diatur dalam hukum pidana positif indonesia dengan hukum pidana islam. Pertama memiliki formulasi sanksi pidana mati, pidana penjara, pidana denda, pencabutan hak-hak tertentu, perampasan barang-barang tertentu, pengumuman putusan hakim, uang ganti kerugian. Kedua mengatur pidana pokok, pidana pengganti, dan pidana tambahan. Hukuman yang diberian sama-sama berupa pemberian sanksi terhadap delik-delik tertentu baik secara tunggal, kumulatif, alternatif maupun alternative kumulatif.

Letak perbedaan antara keduanya terlihat pada pelaksaan pidana mati, yang mana didalam system hukum pidana positif Indonesia tata cara pelaksanaan pidana mati dilakukan dengan cara ditembak sampai mati oleh tim yang telah diberikan manadat secara legal amanat oleh negara dalam hal ini undang-undang. Pada jenis pidana mati pada hukum pidana positif Indonesia tata cara pelaksanaan pidana mati dilakukan dengan cara ditembak sampai mati oleh regu penembak, sedangkan hukuman mati pada hukum pidana islam mempunyai tata cara dan teknik yang bervariasi, seperti dirajam, qisasa dengan menggunakan alat/pedang dan sebagainya. Untuk jenis pidana penjara belum ditemukan system seperti apa yang digunakan dalam pemenjaraan dalam hukum pidana islam, namun didalam hukum pidana positif Indonesia itu sendiri sistem yang digunakan pada konsep pidana penjara ini menganut sistem pemasyarakatan narapidana.

Indonesia pada saat ini sangat membutuhkan berbagai macam kajian mengenai konsep sanksi pidana dalam rangka mereduksi nilai-nilai Islami melalui seminar forum kajian ilmiah serta penelitian, dan lainnya yang 
Reski Anwar

akan dapat memberi kontribusi terhadap pembaharuan hukum pidana serta perlu adanya formulasi jenis penghukuman berupa kerja sosial serta penyelesaian perkara di luar pengadilan (restorasi justice). 


\section{DAFTAR PUSTAKA}

Ahmad Wardi, Muslich, Pengantar dan Asas Hukum Pidana Islam (Fikih Jinayah), (Sinar Grafika: Jakarta, 2004).

Ahmad Wardi, Muslich, Pengantar dan Asas Hukum Pidana Islam (Fikih Jinayah), (Sinar Grafika: Jakarta, 2005).

Alfaruk, Asadullah, Hukum Pidana dalam Sistem Hukum Islam, (Penerbit Ghalia Indonesia: Bogor, 2009).

Ali, Ahmad, Keterpurukan Hukum di Indonesia, (Penerbit Ghalia: Indonesia, Bogor Cetatakan ke- II, 2005).

Atmasasmita, Romli, Sistem Peradilan Pidana kontemporer, (Jakarta: Penerbit Kencana, 2010).

Badri Yatim, Sejarah Peradaban Islam, (Jakarta: PT Raja Grafindo Persada, 2004).

Barda Nawawi Arief, Muladi, Teori-Teori dan Kebijakan Pidana (Edisi Revisi), (Alumni: Bandung, 2005.)

H. M. Arifin, Hamid, Hukum Islam Perspktif Keindonesiaan (Sebuah Pengantar dalam Memahami Realitasnya di Indonesia), (Edisi Internal: Palu, 2008).

Hamzah, Andi, Asas-Asas Hukum Pidana, (Rineka Cipta: Jakarta, Cetakan ke-III, 2008).

Leden Marpaung, Proses Penanganan Perkara Pidana (Penyelidikan dan Penyidikan), (Sinar Grafika: Jakarta, 2009).

M., Sholehuddin, Sistem Sanksi dalam Hukum Pidana: Ide Dasar Double Track System dan Implementasinya, (PT Raja Grafindo Persada: Jakarta, 2007).

Moeljatno, KITAB UNDANG-UNDANG HUKUM PIDANA (KUHP), Jakarta: PT. Bumi Aksara, 2001).

Saleh, Roeslan, Stelsel Pidana di Indonesia, (Bina Aksara: Jakarta, 1987).

Sudarto, Kapita Selekta Hukum Pidana, (Alumni: Bandung, 2001). 
Reski Anwar

Titik Triwulan Tutik, Pengantar Ilmu Hukum, (Prestasi Pustaka: Jakarta, 2006).

Topo Santoso, Membumikan Hukum Pidana Islam: Penegakan Syariat dalam Wacana dan Agenda, (Gema Insani Press, 2003). 